\title{
Stumpage dimensions and stumpage value
}

\author{
DIETMAR W. ROSE
}

Department of Forestry lowa State University, Ames, lowa Journal Paper No. J-7407 of the lowa Agriculture and Home Economics Experiment Station, Ames, lowa. Project 1950.
Dimensions et valeur du bois sur pied. Des analyses économiques poussées requièrent une connaissance de la valeur de croissance du peuplement. Une fonction simplifiée de la valeur du bois sur pied a été établie pour le pin gris au moyen de données fragmentaires reliant les dimensions du bois sur pied au prix de ce dernier. Ainsi, la simulation de la politique d'aménagement du pin gris utilisant cette valeur du bois sur pied en fonction d'une valeur constante, indépendante de la qualité de la station et de l'âge illustre la relation qui existe entre la valeur actuelle nette et les diverses hypothèses sur la valeur du bois sur pied.
In the evaluation of timber management policies a knowledge of both volume and value growth of individual stands is often desirable. Value growth depends on a large number of variables. The measurement of these variables is often difficult and costly, and an analysis involving many variables can become very complex.

Tree dimensions are important determinants of timber prices and, thus, value growth because they influence timber quality, yields per acre, and also harvesting costs. A simple value growth model can be constructed by combining price records with variables such as age and site quality which are correlated with dimensional characteristics of trees (Rose and Brodie 1972). Regional guidelines for economically feasible harvesting operations in the form of minimum average tree dimensions of harvest stands are useful in establishing the linkage between timber prices and average tree dimensions for such a model.

Harvesting of jack pine (Pinus banksiana Lamb.) in northwestern Wisconsin is considered economically feasible if the average stem in a stand reaches a top diameter of 3 inches at $9 \mathrm{ft}$ height and therefore yields at least two 4-ft sticks of pulpwood provided there is a minimum volume per acre of one to two cords.

A Lake States yield table (Gevorkiantz and Duerr 1938) and a taper table for jack pine (Gevorkiantz and Olsen 1955) were used to construct curves describing average diameter at $9 \mathrm{ft}$ height as a function of stand age and site index (Fig. 1). From these curves, the minimum feasible harvesting age could then be determined for different sites.

For each site index three minimum ages were determined: first, the age at which a 3 -inch top at 9-ft height was reached (lowest feasible limit for harvesting); second, the age at which a stand reached a 4-inch diameter at 9 -ft height (the bulk of pulpwood stumpage harvested in recent years had approximately these dimensions); and finally, the age at which a stand reached the minimal dimensions for a sawtimber harvest or 10 inches average $\mathrm{dbh}$ according to a rule of thumb. These three points covered largely the dimensional range of actual jack pine stumpage sales.

Price records (University of Wisconsin, Extension Service 1950-1971), combined with the minimum feasible ages for harvesting were used to establish points for the value-age relationship. It was assumed that at the minimum feasible age for harvesting the lower limit of pulpwood stumpage prices, approximately $\$ 4$ per cord, could be obtained. Stumpage values for ages below the feasible age were assumed to be zero. A second point was plotted by assuming that a cord in a stand of average stem dimensions with 4-inch top at 9-ft height was worth the average pulpwood stumpage price of about $\$ 6$. The stumpage value at the age at which a stand reached lower sawtimber dimensions was the third point and was assumed to be at the lower limit of sawtimber stumpage prices of approximately $\$ 8$ per cord. To derive value functions the established points were then connected by straight line segments (Fig. 2).

Whether or not such stumpage value functions can be used for stumpage appraisals depends on the specific purpose and the context of their use. Stumpage values for individual stands may fall off the established relation because of the inherent error of the derivation technique. Furthermore, prices in the real world are never certain. Therefore, it might be preferable to consider uncertainty over a bounded

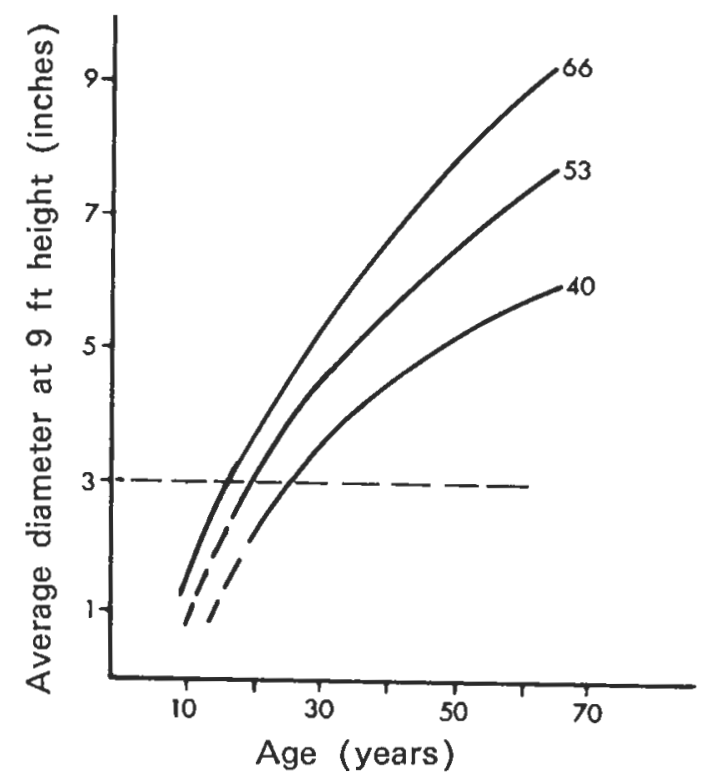

Fig. 1. Average diameter at nine feet height as a function of stand age and site index. 


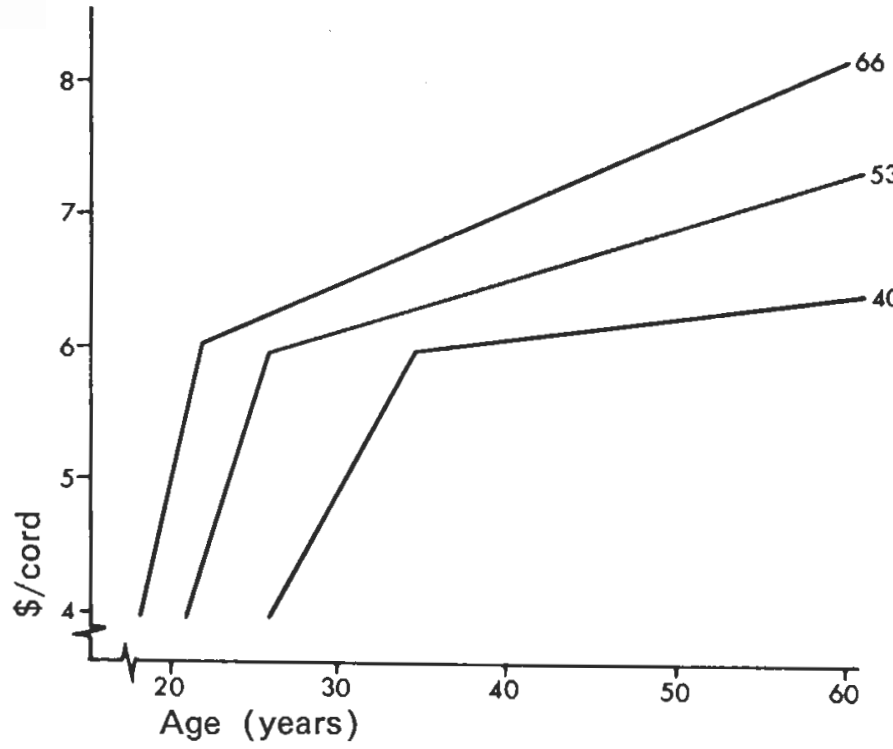

Fig. 2. Jack pine stumpage value functions for three site indexes.

range of prices. Consideration of uncertainty, however, greatly complicates the process and would not be necessary in every context.

The validity of the approach depends on two factors. First, it is important that stumpage products are clearly differentiated with respect to minimum dimensional requirements that can be linked to stand characteristics. To be feasible, the method also requires that prices are reported for well-defined commodity classes or that reasonable assumptions can be made to link price records with stumpage of certain dimensional characteristics.
A simulation of more than 30 management alternatives for jack pine in northwestern Wisconsin over a 50-year planning horizon showed the superiority of short-rotation alternatives over the currently used 50-year rotation with respect to damages by the jack pine budworm (Choristoneura pinus pinus Freeman) and the total present net worth of policies.' However, simulations of these alternatives with the assumption of a constant stumpage price (1971 average of $\$ 6$ per cord) when compared to variable stumpage price drastically changed the magnitude of alternatives on an ordinal scale although rankings remained the same. Thus, simplified stumpage value functions that take account of the value changes with stand age and site index should be used if an ordinal ranking of policy alternatives is required.

${ }^{1}$ Rose, D. W. 1972. Simulation of alternative control strategies for control of jack pine budworm. Uupub. Ph. D. thesis submitted to the Dep. of Forestry, Univ. of Wisconsin, Madison.

\section{Literature Cited}

GEVORKIANTZ, S. R. and W. A. DUERR. 1938. Methods of predicting growth of forest stands. U. S. Forest Serv. Econ. Notes LS 9.59 p.

GEVORKIANTZ, S. R. and L. P. OLSEN. 1955. Composite volume tables for timber and their application in the Lakes States. U. S. Forest Serv. Tech. Bull. LS 1104. 51 p.

ROSE, D. W. and J. D. BRODIE. 1972. A stumpage value function for red pine based on established minimum dimensional requirements of stumpage products. Univ. Wisconsin Forest. Res. Note 163. 3 p.

UNIVERSITY OF WISCONSIN EXTENSION SERVICE. 1950 1971. Wisconsin Forest Products Price Review. Univ. Wisconsin, Dep. Forestry Extension Service, Madison.

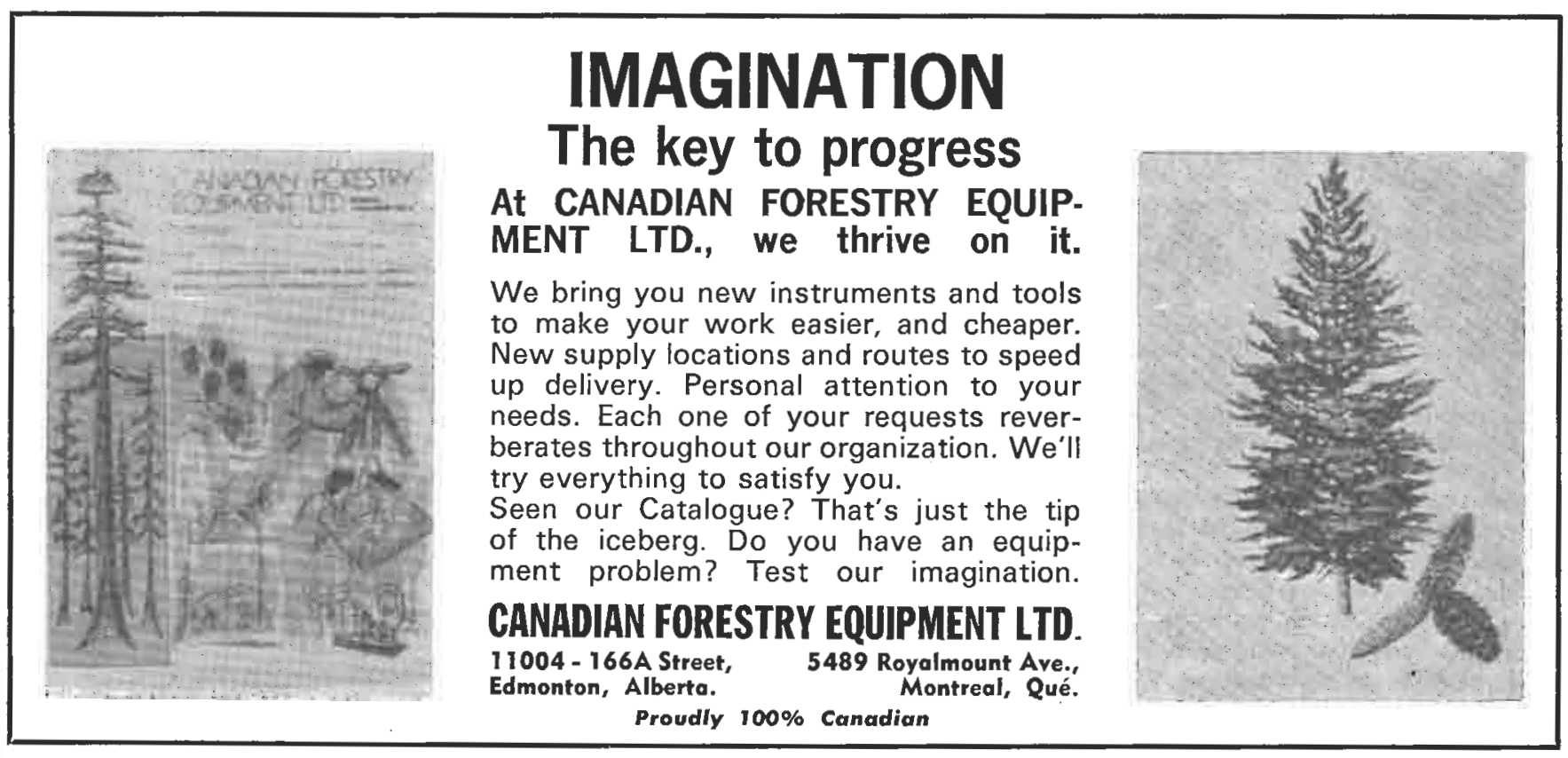

